\title{
Discussion on Management Mode of SMEs Finance Loan in China
}

\author{
Yang shijin \\ College of Economics and Management, South China Agricultural University, \\ Guangzhou, 510642, China \\ crystal_sxj@yahoo.cn,
}

\begin{abstract}
Established in the situation in which China vigorously supports the development of SMEs, the paper aims at business demand and actual progress of large-scale state commercial banks developing SMEs loan, studies status of loan business development and financing demand and field, core business of giving credit for SMEs in compliance with criterion for SMEs stipulated in SME Promotion Law of the People's Republic of China. It is designed to improve prevention mechanism for the SMEs loan development environment and innovate finance loan management mode of SMEs.
\end{abstract}

Key words: SMEs, Finance Loan and Management Mode

\section{Introduction}

According to statistics, capital SMEs obtain from bank loan accounts for more than $90 \%$ in the total financing, which indicates that funds raised from other channels occupies less than 10\%. Unfortunately, SMEs are facing difficulties in raising funds through bank loan due to many causes. Difficulties in getting bank loans have not been solved. The paper analyzes causes for difficulties of SMEs in getting bank loans in the following three aspects, government, enterprises and bank. Therefore, only by deeply and systemically analyzing difficulties SMEs are facing with in getting bank finance from the above-mentioned three factors can we figure out practical ways to solve the problem.

\section{Policy Background of SMEs Loan}

According to survey conducted by China Banking Regulatory Commission, it is found that large banks tend to "encourage large-sized enterprises to apply for loan and discourage small and medium-sized enterprises to apply for loan", which increases difficulties of SMEs in financing and thus causes capital chain tension for a large number of SMEs and quite a few even go bankrupt. After that, banks have paid more attention to SMEs in financial credit and offered more financial support.

\section{Status of SMEs Loan Financing in China}

As SMEs have limited equity fund and are facing with difficulties in various financing channels like non-governmental financing, SMEs mainly raise funds from financial institutions. Generally speaking, SMEs are incapable of entering standard capital market for direct financing. ${ }^{[1]} \mathrm{Cur}$ rently, SMEs have no access to capital market in China. Guarantee system that offer credit guarantee for SMEs including financial appropriation has just started. Under the current institutions and systems, bank loan remains the main financing channel for SMEs in China. Based on the 
survey conducted by Bank of China in August, 2010, more than 90\% SMEs financing is obtained from bank loan and $65.7 \%$ enterprise models are facing financial strain.

Financial and economic crisis since 2008 has made it more difficult for SMEs to survive and raise funds. ${ }^{[2]}$ In the first half year of 2008, more than 67 thousand above-scale SMEs went bankrupt due to weak demand and finance strain around the country. In the first half year of 2009 when capital flow was faster, SMEs that were heavily hit by the economic crisis still faced with difficulties in raising funds. According to relative data, RMB loan balance of SMEs from financial institutions only accounts for one third, while incremental loan occupies one fourth of total newly-gained loan, far too lower than the average loan growth rate.

\section{Causes for Difficulties of SMEs Loan}

\subsection{Enterprises}

As reform is deepening and policies are more flexible, many people are separate from previous collective or state enterprises and establish their own companies. During this period, some small and medium-sized entrepreneurs who earned the first barrel of gold in the first phrase follow vicious habits, concoct various items, extort by trick or by force and occupy others' funds or property. Therefore, on one hand, SMEs have such an impression on people that they do not keep promises. On the other, with the establishment and improvement of market economy, banks and other financial institutions have run on a commercial basis. Historical lessons and realistic options make them view SMEs as high-risk group of evading debts.

\subsection{Banks}

Bank bears higher risks for SMEs loan:
(1). Bank firstly aims to keep security, circulation and profitability, while SMEs are known for high rate of going bankrupt and breaking promises, which makes it hard for banks to abide by security and profitability principle and grant loans. Based on the survey conducted by Bank of China in August, 2010, more than $90 \%$ SMEs financing is obtained from bank loan and $65.7 \%$ enterprise models are facing financial strain.

(2). "Information asymmetry" makes commercial banks not prefer "SMEs". Fundamentally, "information asymmetry" has double connotations: first, the common existence of "information asymmetry" between SMEs and banks makes banks avoid SMEs; second, actually "information asymmetry" exists in all enterprises in various degrees, but property attribute in large-scale enterprises reduces information asymmetry risks of stateowned enterprises in financing and investment, while property in SMEs increases information asymmetry risk in financing and investment.

\section{Management Mode Innovation of SMEs Loan Financing in China}

\subsection{Improving SMES Loan Manage- ment System}

To respond to changes in market demand and meet the demand for SMEs finance loan, domestic commercial banks, under the guidance of China Banking Regulatory Commission, start to build process bank. More and more banks realize that traditional competitive mode that focuses on technology, product and cost can not adapt to changes of market competition. Management concept of "customeroriented" in process bank is gradually accepted by more domestic commercial banks.

Through completely learning the experience of credit asset risk management 
in International large-scale banks and combining status of commercial bank development in China, the paper stresses customer relationship management in commercial banks and studies a new credit management system on the basis of Workflow technology.

(1) Loan Application Management Module Based on SME Customers

On this page, multiple information columns are set so that SMEs can find their positions to apply for loans very soon, greatly contributing to successful application for finance loan.

(2). Management of Customer Information

In this item, detailed financial information about SMEs will be presented to the bank, including changes of financial data, accounts receivable conditions and conditions of fixed asset and mortgage as well as non-financial information. ${ }^{[3]}$ Through analyzing the abovementioned data, banks can know about the operating situation of SMEs in a more detailed way.

Table 1 Loan Application Management Module

\begin{tabular}{|l|l|l|l|l|}
\hline $\begin{array}{l}\text { First-Level } \\
\text { Module }\end{array}$ & $\begin{array}{l}\text { Second-Level } \\
\text { Module }\end{array}$ & $\begin{array}{l}\text { Third-Level } \\
\text { Module }\end{array}$ & $\begin{array}{l}\text { Role of } \\
\text { Module }\end{array}$ & Operation \\
\cline { 1 - 4 } $\begin{array}{l}\text { Business Appli- } \\
\text { cation }\end{array}$ & $\begin{array}{l}\text { Loan Applica- } \\
\text { tion }\end{array}$ & $\begin{array}{l}\text { Loan Application } \\
\text { for SMEs }\end{array}$ & $\begin{array}{l}\text { Processing } \\
\text { for SMEs } \\
\text { Loan Appli- } \\
\text { cation }\end{array}$ & $\begin{array}{l}\text { Searching, Check- } \\
\text { ing, Adding, } \\
\text { Modifying, Delet- } \\
\text { ing and Submit- } \\
\text { ting }\end{array}$ \\
\cline { 1 - 3 } $\begin{array}{l}\text { Credit Business, } \\
\text { Repayment } \\
\text { Business, Giving }\end{array}$ & $\begin{array}{l}\text { Large-scale En- } \\
\text { terprise Appli- } \\
\text { cation,SMEs } \\
\text { Application, etc. }\end{array}$ & $\begin{array}{l}\text { Enterprise Details, } \\
\text { Loan Amount, } \\
\text { Repayment Date, } \\
\text { Guarantor, etc. }\end{array}$ & & \\
\hline
\end{tabular}

Table 2 Financial Information on Customers

\begin{tabular}{|c|c|c|c|c|c|c|c|}
\hline Sequence & 1 & 2 & 3 & 4 & 5 & 6 & 7 \\
\hline \multirow[b]{2}{*}{ Column } & $\begin{array}{l}\text { Financial } \\
\text { Data }\end{array}$ & $\begin{array}{l}\text { Accounts } \\
\text { Receivable }\end{array}$ & $\begin{array}{l}\text { Accounts } \\
\text { Payable }\end{array}$ & $\begin{array}{l}\text { Fixed Asset } \\
\text { and Mortgage }\end{array}$ & Loan Records & $\begin{array}{l}\text { Repayment } \\
\text { Records }\end{array}$ & $\begin{array}{l}\text { Bank Evalua- } \\
\text { tion }\end{array}$ \\
\hline & \begin{tabular}{|l|} 
Asset Scale, \\
Cash Flow, \\
Perfor- \\
mance, etc.
\end{tabular} & $\begin{array}{l}\text { Loan, Divi- } \\
\text { dends, Stock } \\
\text { Ownership, } \\
\text { etc. }\end{array}$ & $\begin{array}{l}\text { Salary, Pur- } \\
\text { chase, Of- } \\
\text { fice, Interest, } \\
\text { etc. }\end{array}$ & \begin{tabular}{|l|} 
Mortgage \\
Scale, Time \\
and Conditions
\end{tabular} & $\begin{array}{l}\text { Loan Date, } \\
\text { Amount and } \\
\text { Management }\end{array}$ & $\begin{array}{l}\text { Repayment } \\
\text { Date, Repay- } \\
\text { ment Capacity, } \\
\text { etc. }\end{array}$ & $\begin{array}{l}\text { Excellent, } \\
\text { Good, Ordi- } \\
\text { nary, } \\
\text { Pass Bad }\end{array}$ \\
\hline
\end{tabular}

Table 3 Non-Financial Information on SMEs

\begin{tabular}{|l|l|l|l|l|l|l|c|}
\hline $\begin{array}{l}\text { Se- } \\
\text { quence }\end{array}$ & \multicolumn{1}{|c|}{1} & \multicolumn{1}{c|}{2} & \multicolumn{1}{c|}{3} & \multicolumn{1}{c|}{4} & \multicolumn{1}{c|}{5} & \multicolumn{1}{c|}{6} \\
\hline Column & $\begin{array}{l}\text { Business } \\
\text { Contact }\end{array}$ & $\begin{array}{l}\text { Operating } \\
\text { Risks }\end{array}$ & $\begin{array}{l}\text { Investment } \\
\text { Schedule }\end{array}$ & $\begin{array}{l}\text { Credit } \\
\text { Conditions }\end{array}$ & $\begin{array}{l}\text { Social } \\
\text { Feedback }\end{array}$ & $\begin{array}{l}\text { Giving Cre- } \\
\text { dit Situation }\end{array}$ & Remark \\
\hline Contents & $\begin{array}{l}\text { Cooperation, } \\
\text { acquisition, } \\
\text { group and } \\
\text { alliance }\end{array}$ & $\begin{array}{l}\text { Hedium } \\
\text { Low }\end{array}$ & $\begin{array}{l}\text { Long-term } \\
\text { Medium-term } \\
\text { Short-term }\end{array}$ & $\begin{array}{l}\text { Excellent } \\
\text { Good } \\
\text { Ordinary }\end{array}$ & $\begin{array}{l}\text { Excellent } \\
\text { Good } \\
\text { Ordinary }\end{array}$ & $\begin{array}{l}\text { Excellent } \\
\text { Good } \\
\text { Ordinary }\end{array}$ & \\
\hline
\end{tabular}




\subsection{Developing Diversified Loan Va- rieties \& Enriching Loan Market for SMEs}

(1). Professional Financial Products

Although there are many corporate financial products in the financial market, they can not meet the demand for SMEs loan. As SMEs are specialized in different fields, banks can design different loan products based on different professional divisions, one product for one division, to meet the professional customer group of SMEs. ${ }^{[4][5]}$

(2). Dividing SMEs Loan Product Market in Different Industries

As SMEs involve different industries, commercial banks can classify loan varieties according to divisions of different industries, ${ }^{[6]}$ for example, exportoriented enterprises, and formulate corresponding loan mode and risk control measures on the basis of the overall risk features of different industries.

(3). SMEs in Upstream and Downstream Industry Chain of Large-scale Enterprises

Dependent on upstream and downstream industry chain of large-scale enterprises, commercial banks can develop loan products for SMEs who specially provide upstream and downstream product services for large-scale enterprises and take the industrial links between SMEs and large-scale enterprises as a measure to control fund flow and repayment sources and monitor loan risks. ${ }^{[7]}$

(4). Inventory financing can act as a key way for commercial banks to grant loans for SMEs

Inventory purchased by SMEs is put in the warehouse designated by commercial banks to provide cautio pignoratitia for bank loan. Companies are required to present delivery order issued by the bank with the stamp before picking up goods. Sales of goods fund is used for paying off bank loan in advance or taking new inventory provided and supplemented separately by SMEs as pledged goods. It solves the problem that SMEs find it hard to get bank loans due to insufficient guaranty and meanwhile helps banks control loan fund flow, and provides repayment guaranty for banks, since inventory pledge loan has quite low risk.

(5). Properly Introducing Project Financing

For the demand for large-scale financing of SMEs, like applying for loan amount of more than 500 million yuan, commercial banks can adopt project financing to provide credit support for SMEs indirectly.

\subsection{Establishing New Bank-Enterprise Partnerships}

(1). Channel is an effective tool to build good bank-enterprise relationships

A good channel can not only meet all demand of customers, but also effectively reduce high human resource cost and operation cost in the bank. ${ }^{[8]}$ Channels serving SMEs customers shall be built in the following aspects: first, building online corporate banking for SMEs to offer 24-hour services that operates easily and safely; second, building intelligent telephone banking for SMEs customers to provide consultation, trade and financial management services; third, researching and developing secure credit banking for SMEs to offer such services as remittance and trade. Diversified channels will become a light spot and feature of China Merchants Bank in serving SMEs customers. Examination and approval procedures in Figure 4 can effectively expand channels for bank-enterprise communication. 
Table 4 Examination and Approval Procedures

\begin{tabular}{|c|c|c|c|c|c|c|c|}
\hline $\begin{array}{c}\text { Se- } \\
\text { quence }\end{array}$ & 1 & 2 & 3 & 4 & 5 & 6 & 7 \\
\hline Column & $\begin{array}{l}\text { Customer } \\
\text { Information } \\
\text { Examination }\end{array}$ & $\begin{array}{l}\text { Customer In- } \\
\text { formation } \\
\text { Reexamination }\end{array}$ & $\begin{array}{l}\text { Authorization } \\
\text { for Modifying } \\
\text { Customer In- } \\
\text { formation }\end{array}$ & $\begin{array}{l}\text { Loan Reex- } \\
\text { amination } \\
\text { Suggestion }\end{array}$ & $\begin{array}{l}\text { Summarization } \\
\text { and Analysis }\end{array}$ & $\begin{array}{l}\text { Comparative } \\
\text { Analysis }\end{array}$ & $\begin{array}{l}\text { Decision on } \\
\text { Loan }\end{array}$ \\
\hline Contents & $\begin{array}{l}\text { Conducting } \\
\text { initial exami- } \\
\text { nation to en- } \\
\text { sure no ob- } \\
\text { vious slips }\end{array}$ & $\begin{array}{l}\text { Deeply analyz- } \\
\text { ing informa- } \\
\text { tion and im- } \\
\text { proving quality }\end{array}$ & $\begin{array}{l}\text { Reminding } \\
\text { customers to } \\
\text { modify infor- } \\
\text { mation }\end{array}$ & $\begin{array}{l}\text { Putting for- } \\
\text { ward reex- } \\
\text { amination } \\
\text { suggestion }\end{array}$ & $\begin{array}{l}\text { Summarizing } \\
\text { and analyzing } \\
\text { data in all as- } \\
\text { pects }\end{array}$ & $\begin{array}{l}\text { Analyzing the } \\
\text { possibility of } \\
\text { applying for } \\
\text { loans }\end{array}$ & $\begin{array}{l}\text { Approving } \\
\text { or rejecting } \\
\text { loan applica- } \\
\text { tion }\end{array}$ \\
\hline
\end{tabular}

(2). Service can contribute to improving bank-enterprise relationships

It is an important and prominent theme of competition in foreign banks to distinguish "product", direct value in use offered by the bank to customers, "channel", indirect value in use and "service", added value offered by the bank and conduct specialized management respectively. ${ }^{[9]}$ Service for SMEs customers is divided into basic service and value-added service. Basic service stresses employee's quality, in other words, matter receptionists or front-line customer service manager and product manager can have customers convinced with unparalleled and high quality. SMEs customers can give priority to China Merchants Bank for value-added services and choose outsourcing, because express company will send checks and bill collection through special express services.

\subsection{Improving Credit Guarantee Me- chanism For SMEs}

Since 1998, China has built credit guarantee mechanism for SMEs to solve difficulties of SMEs in credit guarantee by learning the common way in the world. Relative departments shall build several policy companies specially designed for credit guarantee for SMEs. ${ }^{[10]}$ The state shall issue a policy on building risk and finan- cial compensation mechanism respectively and encourage funds in all economic sectors to participate in the investment of guarantee companies in the hope of gradually shaping multilevel credit guarantee system for SMEs that combines national, regional and community-based guarantee institutions to ensure secure and stable operation of credit guarantee institutions for SMEs and spread operational risks.

The paper only discusses external factors of financing system for SMEs. However, to fundamentally solve "bottleneck" problems of SMEs, external system building is far from enough. SMEs shall, starting from themselves, enhance corporate quality, improve internal system and establish and perfect modern property rights and internal financial control and management system to improve profitability. Only by combining internal improvement and external environment construction can solve financing difficulties of SMEs step by step.

\section{References}

[1] Y. Huihui, and W. Xigang, "Study on Small and Medium-sized Enterprises Financing in China [J]," Market Modernization Magazine, $7^{\text {th }}$ edition, 2007.

[2] Z. Haixi, "Analyzing Small and Medium-sized Enterprises Financing in China [J]", New West, ${ }^{\text {st }}$ edition, 2007. 
[3] Z. Zhao, "Horizontal Marketing Theory and Inspiration [J]", Economic Review, $2^{\text {nd }}$ edition, 2006.

[4] T. Yan, "Development and Innovation of Bank Marketing in China [J]", Finance Review, $7^{\text {th }}$ edition, 2004.

[5] X. Junyang, and S. Tao, "Training Methods of Bank Marketing Capacity [J]", China Finance, $1^{\text {st }}$ edition, 2004.

[6] Z. Xianbing, "Inside Control Construction of Foreign Commercial Bank and Its Significance [J]", China Finance, $10^{\text {th }}$ edition, 2002.

[7] X. Jun, "Reference and Thinking of Marketing Strategies of Commercial Bank Loan [J]", Finance Review, $9^{\text {th }}$ edition, 2002.

[8] Z. Rui and X. Xueliang, "Five Actions to Open the Deadlock in Private \& Collective Enterprises' Finance [J]", Corporate Culture, $8^{\text {th }}$ edition, 2002.

[9] C. Guo and W. Defu, "Research on Indirect Financing Countermeasure for China's Small and Medium-Sized Enterprises [J]", Journal of Chongqing Jianzhu University, $1^{\text {st }}$ edition, 2002.

[10] L. Haiyan, "Establishment and Development of Credit Rating System of China's Banking Sector [J]", New Finance, $10^{\text {th }}$ edition, 2001. 